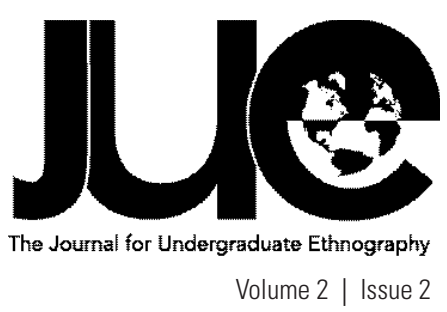

\title{
Radical Campus? Student Participation in the SFU Left Alternative Club
}

\section{Brett Zeleznik}

Simon Fraser University, bzelezni@sfu.ca

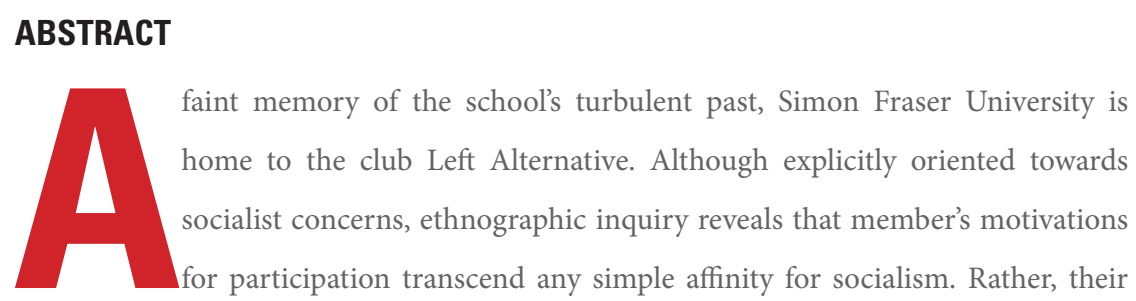

involvement in the club speaks to a number of factors that are multifaceted and without

overt intent. Through interviews and participant observation, balanced with material analysis and autoethnography, the causes of participation in Left Alternative appear threefold. Member's involvement presupposes an interest in education, both of oneself and others, a desire to correct social ills, and an implicit need to affirm struggling notions of self.

Keywords: Club Participation, Socialism, Identity Affirmation, Education, Activism 


\section{INTRODUCTION}

Officially a celebration of Simon Fraser University's (SFU) distinctive vision, for many the slogan heading its 40th anniversary, "radical by design" (Stevenson 2005), instead speaks to the early struggle between administration and the student-faculty coalition of the Political Science, Sociology and Anthropology Department (PSA). Culminating in the three-day occupation of the administration building, and the subsequent arrest of 114 activists, the late 1960s were home to a bitter dispute over the status of post-secondary education. The opinion of the PSA, and of the Students for a Democratic University, was that decisionmaking should be democratized, which meant the transfer of power from the board of governors to students and faculty. By 1969, the school had seen the removal of a president, strikes by faculty, numerous protests, and extra-curricular initiatives to nurture 'left' sentiments, earning SFU the title of "Berkley North" (Johnston 2005).

Though the PSA has dissolved, and its student leaders have moved on, the memory of the school's turbulent past prevails. Atop the rainy Burnaby Mountain, just east of Vancouver, SFU is heralded as one of western Canada's most prominent leftist universities. In fact, it was precisely this status that prompted me to enroll. While attending a smaller college, it had come to my attention that even the simple pleasure of transferring credits to SFU was influenced by early militant students. I wished to become a part of this tradition. However, the experience did not live up to expectations. Despite there being an abundance of issues, protests seemed few and far between. Of all the clubs on campus, only a handful seemed concerned with student politics, and even these lacked substantial membership. In 2001, in an attempt to understand this anomaly, I sought out one of SFU's most obvious left clubs: Left Alternative.

Although the name of the club carries the political term left, Left Alternative is a club oriented primarily towards socialist concerns. However, this is not to say that the club is dogmatic and intolerant of non-socialist ideas. In my experience as both an active member of the club and an observer, it was apparent that neither the founders of Left Alternative, nor any of its members, were closed to ideas which were not of a socialist leaning. In fact, in the two months I spent researching, it became clear that socialism, while many members saw it as the logical solution to the problems of capitalism, did not dominate discussion. This was surprising considering the recruitment leaflet for the club states: "We believe that people can change things for the better. A socialist society is possible" (See Figure 1). To my amazement, Left Alternative did not appear to be a club full of die-hard socialists, planning their advance and the ultimate overhaul of society.

Why then do students participate in Left Alternative? In this research I examine this question from the perspective of a sympathetic researcher, an active member of the club, and an insider. By attempting to gauge this question a number of related factors are revealed, including the motivations of members, their objectives for Left Alternative, and the labels they identify themselves with. I argue that student participation in Left Alternative is closely related to educational goals, both in terms of the desire to learn and to educate others. It is further argued that participation is a result of member's desires to involve themselves in activism and find practical solutions to the ongoing social problems they are aware of. Finally, it is demonstrated that members exhibit an implicit need to interact with people who identify themselves in a similar manner, thereby reaffirming their own identity.

\section{LITERATURE ON CLUB PARTICIPATION}

Granted that the current literature on club participation is primarily concerned with post-secondary students (Arbodela et al. 2003; Burns et al. 2006; Case 2011; Gilbreath et al. 2011; Knowles and Gardner 2008), it would seem that this research, in having a likewise focus, is limited in its contribution to the literature on club participation. However, the current literature lacks any substantial investigation of the topic with regard to qualitative methodology (Arbodela et al. 2003; Burns et al. 2006; Case 2011; Gilbreath et al. 2011). Even where post-secondary students were not a factor, strictly quantitative techniques still prevailed (Planalp and Trost 2009). These studies all employed closedanswer questionnaires which, given their limitation of responses to impersonal categories, failed to fully apprehend the underlying meaning of participant's experience. An attempt to rectify this problem is found in Knowles and Gardner's (2008) study, where participants were asked to write, in as much detail as possible, their innermost convictions regarding particular social events. To get at the heart of post-secondary student's participation in clubs, it is necessary to expand on Knowles and Gardner's (2008) 


\section{LEFT ALTERNATIVE}

In the past ten years the costs of a post-secondary education has increased $119 \%$ in BC. Canadian troops have fought in Afghanistan for almost a decade, things there are no better, but many Afghans and Canadians have died. Canada has been fighting in Afghanistan for almost ten years with no end in sight. Social and economic inequality is increasing in Canada and worldwide. Big business is damaging the environment to make profits. We believe that people can change things for the better. A socialist society is possible. Find out more and join Left Alternative.

Left Alternative SFU will discussing and campaigning on issues including: against imperialism and discrimination; in support of workers' struggles; and for accessible education, environmental sustainability and socialist democracy. Come and join the discussion!

Our first meeting is on September $21^{\text {st }}$ the topic will be 'What is Socialism?' Subsequent topics are TBA depending on members' interests.

Meet: Wednesdays from 10:30 to 11:30pm

Where: Bennett Study Room 2102 Contact: leftalternative2010@gmail.com 
approach, further allowing participant's to express their own meaning. Such an approach guides this research.

A further contribution to the literature on club participation consists in the lack of inquiry into specific post-secondary clubs. The current literature tends to analyze clubs as a general category (Arbodela et al. 2003; Burns et al. 2006; Case 2011; Gilbreath et al. 2011; Knowles \& Gardner 2008). Hence, Case's (2011) research demonstrated an interest in collegiate clubs which "represented a broad range of co-curricular activities available to college students" (174). This approach is also apparent in Burn et al's (2006) study of undergraduate marketing students, where participants were assessed on the basis of their involvement in a general assortment of clubs and associations. Surely, such generalizations are important to uncovering common causes of club participation, but they are unable to investigate the specific causes inherent to individual clubs. Each club, being distinct from others, inevitably has a different appeal to the student and procures their participation in different ways. Not only does this research explore the dynamics of a single club, but it might provide insight into the causes pertaining to a club type - that of socialist or left clubs.

Concerning club participation in general, three explanations stand out in the current literature. First, there exists a positive relationship between on-campus residency and club participation (Arboleda et al. 2003; Case 2006). While Arboleda et al. (2003) suggests that greater satisfaction with residence life contributes to involvement in clubs, Case (2011) accounts for the relation by concluding that on-campus residency simply affords more opportunities to engage with clubs, and therefore enhances the likelihood of participation. However, each hypothesis only identifies a correlation, yet does not unearth exactly why students participate in the clubs they do. Perhaps the relationship is not causal, but only coincidental, and is reducible to a third, unaccounted element. In this research, I examine the claims of Arbodela et al. (2003) and Case (2011), probing students themselves for any indication of a self-claimed causal relationship between residency and club participation.

Another explanation present in the current literature involves social identity theory, which explores the interaction between one's sense of self and their perceived belonging to the social group (Brym 2008). Gilbreath et al. (2011) found that the extent to which post-secondary students define themselves according to varsity sports teams, academic majors, or as students of the institution, greatly affects their involvement in campus activity. Their identification with these symbols permits entrance into a community of likewise identified persons, fostering interaction between them. Where their inclusion in the community is threatened, Knowles and Gardner (2008) note that people unwittingly amplify the meaningfulness and personal importance of the group, thereby sustaining a sense of belonging. A threat to their membership becomes a threat to their sense of self. This research explores the possibility of Left Alternative as providing a community to which the identities of students are intimately entwined. If integral to the preservation of certain notions of self, their participation might implicate social identity theory in an understanding of participation in clubs of this type.

Third, employing a rational actor model, Olsen (2009) asserts that an individual's choice to participate in any social activity results from an innate desire to maximize personal benefits and minimize costs. Therefore, to participate in a group that strives for a "public good" (62) would be irrational, as a member of the same group would receive the benefit of the good without helping to attain it. Accordingly, Olsen (2009) stresses the importance of "selective incentives" (64) - benefits offered by a group which are only attributable to individuals. For Olsen (2009), participation in group activity requires the existence of selective incentives. Following this, I examine the degree to which member's participation in Left Alternative is dependent on selective incentives. This research also serves to evaluate Olsen's (2009) notion of people as rational actors, supporting or repudiating its authority in the current literature.

\section{RESEARCH SITE AND METHODS}

Every week the Left Alternative club meets in a room located on the SFU campus to discuss issues relevant to socialism. The members of the group are all SFU undergraduate students, with the exception of a Masters student in history. The organizer books the rooms and sends out an email to each member of the group in advance of meetings. Since there was considerable competition for rooms during research, it was not possible to schedule every meeting in the same room. Therefore, weekly discussions took place in either the Education Building, located on the North side of the Academic Quadrangle, or on 
the second floor of the Bennett Library. While certain rooms in each region were often used more than once, the rooms themselves were quite similar in appearance and structure. Each had a single table, either square or circular, with chairs placed around it. This was fruitful in terms of creating a space in which all members were comfortable to share their opinions and engage in discussion. Other similarities consisted in the fact that all the rooms were of a rectangular shape, were large enough to hold approximately fifteen people, and had whiteboards which aided in illustrating members points during discussion.

Although I had joined Left Alternative only a month prior to research, my dual presence throughout October and November, as both a member and researcher, was welcomed. In fact, I quickly became friends with a number of the participants and am still currently. This was beneficial in terms of obtaining the consent of members to be observed during meetings. When this concern was brought to their attention, they were incredibly receptive to the research objectives, and even encouraged the project. Since different members frequently showed up to meetings each week, approval of the research was asked for on several occasions, warranting positive responses each time. Their consent was attained verbally, and it was agreed that their identities would remain confidential. In this report, all members are represented with a designated alias.

The methods employed include participant observation, interviews, material analysis, and auto-ethnography. Meetings took place every week at 10:30 am on Wednesday. I attended eight of a total nine meetings during research, observing and participating in the discussion which took place. The number of members at each meeting ranged from four to seven. Although discussions were frequently high-spirited and jovial, the group would generally discuss topics which focused on the problematic nature of society. These topics included such things as abortion, state authority, imperialism, colonialism, homelessness, poverty, etc. While the data gathered by means of observation helped to find themes to be explored during interviews, such as "meaning of socialism," "self-identification," "opinion of global protests," "first experience of socialism", "on-campus club involvement," "homogeneity of perspectives at meetings," this method was challenging. As a participant-observer, it was difficult to capture every potentially useful interaction, statement, and gesture. However, by sustaining participation in discussions, I was able to build rapport with the members of Left Alternative. This was beneficial for finding interview respondents, as members were more willing to participate, particularly Luke, a fourth year student who, upon hearing that I intended to conduct interviews, offered himself as the first participant. In addition, this rapport allowed for me to build relationships with members that extended beyond association in Left Alternative. By engaging with members outside of Left Alternative meetings, a deeper understanding of the participants was possible. As a result, interviews were able to gauge the research question in a manner which was more closely related to specific individuals. For example, my friendship with Chris revealed to me that he is an active member of Socialist Alternative Canada, a national socialist organization oriented towards activism. With this understanding, I was able to inquire into his involvement in Socialist Alternative during our semi-structured interview, and how this relates to Left Alternative. If I did not have this knowledge prior to the interview it may have been difficult to gain insight into Chris's affinity for socialist activism.

Apart from the interview with Chris, three others were conducted, each in a different format. The formats used were semi-structured, structured, and unstructured. Although Luke volunteered himself for an interview, the other three participants were selected on the basis of maximum variation. They were purposefully chosen according to characteristics of interest, such as attendance of meetings, year of studies, gender, and field of studies. For all categories an attempt was made to ascertain individuals who represented a wide range of variability. For instance, although this was not the primary reason for selection, Penelope was chosen because she was in her fourth year of studies, while Sandra was selected because it was her first semester of post-secondary education. Each respondent was asked to participate via email so that both their selection and decision to participate or not would be confidential. Emails included a general outline of the ethical responsibilities of the researcher, what participation entails, and the overall conduct and objectives of the research project. This was explained in greater detail at the beginning of each interview. Since my relationship with the members of Left Alternative was strong, every member who was asked to participate accepted.

Observation and interviews were supplemented by material analysis. Open coding was used to analyze text, as 
well as images. Because he founded the club, and is therefore the primary organizer, Chris designed a leaflet to be handed out to interested students during "Clubs Day" in early September. It illustrated a variety of social and economic problems that persist globally and in Canada, following up with an advertisement for the club as a means to discussing and campaigning on these issues. Analysis of this allowed for a greater understanding of Chris's perspective concerning current society, socialism, and the objectives he has for Left Alternative. Along with Alex, another member of Socialist Alternative who on occasion attends Left Alternative meetings, Chris also produced a leaflet that was distributed at the initial rally for Occupy Vancouver on October 15. It emphasized the hardships involved in the current economic crisis around the world and in British Columbia, how these problems might be solved, and an advertisement for a bi-weekly discussion group in downtown Vancouver. Chris also created a leaflet advertising an October lecture at SFU by a member of the German Left Party, organized by Left Alternative. These were analyzed in order to further elaborate on the relationship between Socialist Alternative and Left Alternative, and how this relationship is represented by Chris and Alex. Other materials included an informational leaflet produced by the Seattle branch of Socialist Alternative for the October lecture. Analysis of this permitted an understanding of the objectives of Socialist Alternative as an organization.

Finally, this data was supplemented by auto-ethnography. Following each observation period, I would spend time writing detailed notes regarding my own experience in the situation. This was included with my regular field notes, allowing for a fully reflexive awareness of my own position in the data, and how it relates to the events occurring during weekly meetings. This is especially important when it is acknowledged that I, like many others in the club, was a new member of Left Alternative. As both a new member and an active participant, the insights gained from my experience are invaluable to the research. Additionally, I spent approximately two hours answering each question in the interview guide, recording my responses prior to conducting interviews with other members. Following open coding of interview transcripts, it was possible to analyze themes from the auto-ethnographic interview in conjunction with the other interviews.

\section{EDUCATION}

When I first met Chris, it was on Clubs Day in early September. He was sitting beside Alex at the table for Left Alternative, as a rally carried on behind in support of CUPE in their lockout battle with the SFSS. Lacking a banner, the table was covered by a variety of books and pamphlets representing such themes as the environment, LGBT rights, Malcolm X, imperialism, Marxism, the Russian Revolution of 1917, etc. Having heard of Left Alternative previously, I was aware that the club was oriented towards socialism. But upon seeing the wide array of topics the club concerned itself with, I was intrigued and wished to learn more about socialism. Over the previous summer I had spent a bit of time reading up on socialism. My knowledge of the subject, however, was by no means complete. Left Alternative, then, appeared as an opportunity to learn about something which is so often castigated by mainstream media.

S.YOU ALWAYS
SEETHINGS FROM
A MAINSTREAM
PERSPECTIVE. [THE]
MEDIA SAYS THIS
ABOUT SOMETHING,
BUT I FIGURE IT
WOULD BE GOOD
TO SEE THINGS
FROM A DIFFERENT
PERSPECTIVE,
TO SEE HOW
SOCIALISTS VIEW
THINGS, AND
WHAT SOCIALISM
ACTUALIY IS"- BEN


In our first meeting of the semester, a young second year arts student named Ben, expressed a similar sentiment. At the beginning of the meeting, Chris asked if we could go around the table and introduce ourselves, stating something interesting about ourselves and possibly why we joined Left Alternative. When it was his turn to speak, Ben stated that his interest in Left Alternative was a result of the fact that "you always see things from a mainstream perspective." For him, ideas about socialism, and of socialists particularly, often went unheard. He went on to say that: "[the] media says this about something, but I figure it would be good to see things from a different perspective, to see how socialists view things, and what socialism actually is." Although implicitly, Ben suggests that the idea of socialism espoused by mainstream perspectives may not be accurate, and accordingly his knowledge of the subject is insufficient.

This point was emphasized during informal discussions with other members, particularly Linda, a young Chinese student involved with the Society for Arts and Social Sciences (SASS). Exuding enthusiasm and energy, Linda would often ask myself and other members a variety of questions related to socialism and left politics. Unknown to me at the time that she was involved with the SASS, I attended a lecture organized by the group, and ended up encountering Linda there. At the end of the lecture we discussed a variety of things related to our participation in Left Alternative, at which point she questioned me about the difference between anarchism, socialism, and communism. As I attempted to answer her questions, she elaborated on her reasoning by explaining that her lack of knowledge about these ideas was a product of the fact that she "was never really taught about socialism, anarchism, and that stuff." Emphasizing the point, Linda explained that many of the members of Left Alternative seem to be more knowledgeable of these ideas, particularly Chris and Alex, whom she claims to have learnt the most from.

For Chris, this appears to be precisely the intent he has for the group - to educate others. Since Chris founded the group a little over a year prior to the research, I was able to ask him in our interview why he decided to create Left Alternative. Among the various answers he gave, a prominent one was the desire to educate others about the nature of socialism. This was reflected in the leaflet Chris handed out on Clubs Day. Two-thirds of the way down the paper, it reads "Our first meeting is September 21st the topic will be 'What is Socialism?' Subsequent topics are TBA depending on members' interests" (See Figure 1). Here, it is apparent that there is an emphasis on teaching others about socialism, as well as catering this education towards people's interests. Although the primary relation of members to Left Alternative is for educating one's self, for Chris it is about educating others.

\section{ACTIVISM}

However, Chris's intent for Left Alternative does not end at the education of others concerning socialism. For him, there is a larger purpose closely related to his involvement in Socialist Alternative. Although the organization is not dogmatic, membership implies an interest and dedication to the promotion of socialism over capitalism, and the advancement of this goal by means of active struggle. In an article produced by Socialist Alternative in Seattle, this notion is clearly emphasized. They call upon members and the general population alike to "spread the occupations across the U.S. and into schools and communities," and to "organize weekend mass demonstrations" (See Figure 2).

While lacking in membership and therefore activists, the Canadian branch strives towards the same goals. In our interview Chris repeated this sentiment, stating that the absence of activism by Socialist Alternative in Vancouver is precisely a problem of membership, not of intent. In fact, Chris and Alex are the only two members of Socialist Alternative in the entire Vancouver region, making any form of activism a complicated task. To curb this hindrance, Chris explains that Left Alternative may serve as a means to recruit people to Socialist Alternative. He says that the ultimate goal for Left Alternative is to "have a small group who will actively involve themselves in alternative and left groups, and who will continue the work of networking and education." As I questioned if there was anyone in Left Alternative he thought of recruiting, Chris gestured towards me.

Being a sociology major, one is often made aware of the various problems which afflict society. What is often lacking, 


\section{End the Dictatorship of Wall Street! A Socialist Strategy to Build the Movement}

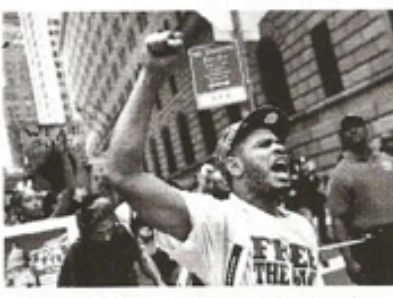

All around the world attention has been drawn to the occupation of Wall Street. The protests has captured the imagination of thousands and inspired new $\propto$ cupations which are spreading across the U.S.

The police crackdown in New York, intended to intimidate this movement, completely failed to break our spirit. Now we are more determined than ever to fight. inspired by the revolutionary upheavals in Egypt and across North Africa, as we as the mass youth occupations in Spain and Greece, protestors have taken to the streets of New York and cities across the U.S. to stand up to the domination of U.S. to Street and Big Business over our lives.

Below the surface there is deep an ger in U.S. society which only seemed to be getting a twisted expression in the right-wing lunatics of the Tea Party. But the mass movement in Wisconsin this spring, and now the occupation of Wall Street provide a glimpse of the enormous potential to turn that anger into a progres sive social movement.

How can we take the struggle forward? Many are occupying to "liberate space" in order to build a new, more equal an just community, hoping it will inspire others to follow. While the Wall Street oc cupation is an example of a community based on democracy, cooperation and solidarity, unfortunately the occupation alone will not be enough to build a mass movement capable of changing society.

Many have alluded to Egypt saying that a growing occupation with one basic demand is how the dictator was overthrown. But in fact, the situation was more complicated than that. In the week before Egypt's dictator Mubarak was ousted, the

\section{CONTACT US}

working class entered the scene with decisive strike action paralyzing key parts of the economy

The occupations in Spain and Greece have been much bigger than Wall Street, but they too need the more powerful forces of the working class to move into action in order to win. In Wisconsin, a huge occupation of the Capitol lasted for over 3 weeks and was at the center of mass demonstrations of the workers and youth. They could have won if that movement had moved toward a general strike of public sector workers to shut the state economy down.

Instead the Wisconsin battle was consciously derailed by the Democratic Party and the top union leadership by diverting the mass movement into a campaign to recall the Republicans from power in order to elect Democrats in their place. However, the Democrats, like the Republicans, are a party of Wall Street and Big Business, and they offer no solutions. We need an independent struggle which seeks to draw in the widest layers of workers and youth. United we have the power to withdraw our labor, stop "business as usual," and hit the banks, corporations and ruling elite where it counts.

We need to build up the confidence to take such bold measures. That's why Occupy Wall Street needs to call for mass demonstrations around key demands that address the burning issues that working people and youth face like jobs, education, healthcare and so on.

\section{System Change}

Not only the economy but society as a whole is in a deep crisis. Global capitalism is a failed system that cannot overcome the problems of growing inequality. poverty, mass unemployment, environmental destruction, and war which it creates. The movement has to challenge Wall Street and both parties of big business. We must stand up to their policies where they crisis on our backs in order to maintain a system which only benefits the elite in the first place.

But we must also provide a clear alternative. We need to fundamentally trans form society to one not based on profit but instead on meeting everyone's basic human needs. The only real alternative to corporate greed and capitalism is democratic socialism where the economy, workplaces, and society as a whole is democratically run by and for the vast majority of people.

\section{Join Socialist Alternativel We say:}

- Spread the occupations across the U.S. and into schools and communities. For systematic, mass campaigning to mobilize the widest layer of workers, young people and labor unions into struggle.

Organize weekend mass demonstrations that call for. No cuts to social services, A massive jobs creation program, Major tax hikes on the super-rich and big business. End the wars, Slash the military budget, and Defend union and democratic rights.

Build up to the November $16-23 \mathrm{Na}-$ tional Week of Action to combat the Congressional Super Committee plan for $\$ 1.5$ trillion in cuts to social services. We demand jobs not cuts!

Prepare to run independent anti-corporate, working-class candidates in 2012 to challenge the policies of the two parties of Wall Street as a first step towards forming a new party of the $99 \%$, a mass workers' party.

End the dictatorship of Wall Street! Bring the big banks that dominate the U.S. economy into public ownership and run them under the democratic management of elected representatives of their workers and the public. Compensation to be paid on the basis of proven need to small investors, not millionaires.

Build the movement to replace the rotten system of capitalism with democratic socialism and create a new society based on human need. 
however, is a means towards their correction. "We read a lot of stuff in books, but it's hard to translate into practice" as Luke so helpfully put it in my interview with him, another sociology student. My involvement, as well as Luke's, is to some degree an attempt to get involved in activism and begin to engage with these problems in a practical manner. Learning of Chris's connection to Socialist Alternative, I discussed with him on various occasions the nature of the organization and expressed an interest in joining. Accordingly, when Chris officially asked me to become a member of Socialist Alternative in late November, both mine as well as Chris's activist goals for Left Alternative were somewhat satisfied. He had gained an ally in the struggle for socialism, and I had discovered an avenue for my activist interests.

Along with myself, Luke was also asked if he would like to join Socialist Alternative. Luke is also very aware of the current state of society, finding in it a great deal of problems. In our interview, Luke was emphatic of the way the education system reproduces misery, stating that "there's so many people today who because they don't have enough money they can't go to university, and therefore they can't develop new skills." This restriction stifles the ability to be creative, and if one cannot be creative, "then your life becomes really really miserable." What is the solution to this problem? For Luke, the answer is to try to change the world. He goes on to say: "and thinking yeah well, if my life is going to be miserable or not, and I don't want it to be, I think the thing we should do is try to change the world." One cannot hope for change, but must actively pursue it. From Luke's perspective, this desire for positive change inevitably leads to socialism - a democratically organized society where the "basic needs of life are not owned privately" and "everything in society is voluntary," allowing for individuals to achieve their fullest potential and be happy. It is in Left Alternative, as well as the resulting affiliation with members connected to activist networks, that positive change and socialism may be striven for.

\section{IDENTITY}

In their influential book The Social Construction of Reality, Berger and Luckmann (1966) assert that one's identity can only be maintained if the individual exists in a "milieu that confirms this identity" (155). While certain identity maintaining techniques may be utilized in the absence of actual social interaction, these techniques cannot sustain the identity in question indefinitely (Berger and Luckmann 1966; Knowles \& Gardner 2008). Gradually, this sense of self loses its legitimacy and becomes distorted, as it is subject to social processes which impose and affirm an alternative identity. The self-identified socialist, then, can only maintain their identity if they are to associate themself with like-minded individuals. While this notion of identity affirmation may not be consciously apparent to the individual, it is clear that there exists an implicit desire for social belonging, as demonstrated by the existing literature on the subject (Gilbreath et al. 2011; Knowles \& Gardner 2008).

This sentiment was evident in my interviews with members of Left Alternative. When asked about his reasons for founding the group, Chris stressed the isolation one feels if they associate themselves with alternative perspectives. These perspectives may lead one to become "frustrated with the way things are," but unless there are other people to share these ideas with, people are left wondering "are there other people out there you can have that conversation with? Or are you sitting in your room being like: am I the only one? " It is this feeling of isolation which restricts the assumption of marginal notions of self. Although each respondent interviewed identified themself according to a left identify (i.e. socialist, communist, anarchist), some were apprehensive in doing so, and even questioned their response once it was stated.

After stating that she identifies herself as a communist, Sandra, an arts student from Surrey, hastily remarked: "but that just sounds pretty extreme." While it is possible that my presence provoked her to downplay this identity, I do not think this was the cause. As a friend of Sandra's, we are particularly comfortable around each other and have often discussed these matters casually outside of Left Alternative. Rather, it seems that Sandra, as a new member of Left Alternative, has only recently begun to engage in relations which confirm this element of her self-concept. Such relations are particularly absent outside of Left Alternative, especially in high school, where she was only introduced to the "facts of Liberalism and Conservatism." As a first year student, Sandra has only recently been removed of the relations present in high school that impose a particular definition of self and repress others. For this reason, she remains hesitant to fully embrace this identity.

Similarly, when I asked Penelope why she joined Left Alternative, she cited the fact that the only people she has ever known to entertain "socialist and other radical ideas" are her dad and a few friends, going on to admit that her choice to pursue an English degree allows for few opportunities to engage with these ideas. She followed this by explicitly stating that her choice to join was because she wanted "to discuss these things with 


\section{“THESE PERSPECTIVES MAY LEAD ONE TO BECOME "FRUSTRATED WITH THE WAY THINGS ARE," BUT UNLESS THERE ARE OTHER PEOPLE TO SHARE THESE IDEAS WITH, PEOPLE ARE LEFT WONDERING “ARE THERE OTHER PEOPLE OUT THERE YOU CAN HAVE THAT CONVERSATION WITH? OR ARE YOU SITTING IN YOUR ROOM BEING LIKE: AM I THE ONLY ONE? " IT IS THIS FEELING OF ISOLATION WHICH RESTRICTS THE ASSUMPTION OF MARGINAL NOTIONS OF SELF. "}

socialists and those sorts of people." Recognizing her implication that she may be a socialist, I asked her if she identified herself in this manner. After a long pause and considerable self-debate over the meaning of certain positions, Penelope reluctantly identified herself as an anarchist. Like Sandra, Penelope appears to associate herself with alternative ideas, but is still unable to fully embrace an identity which represents these ideas.

Removed of social relations that confirm a particular identity, Berger and Luckmann (1966) assert that an individual will doubt themselves concerning this identity. It is this dissociation which causes doubt in Sandra and Penelope, and subsequently what motivates them to participate in Left Alternative. Through interaction in Left Alternative this sense of self may be reaffirmed. Association in Left Alternative has even necessitated relations which extend beyond weekly meetings, as seen in the friendships that have developed between members, and the involvement of many members in another discussion group which is more inclusive of the larger community.

\section{DISCUSSION}

As previously demonstrated, this research supports social identity theory and the hypothesis of Berger and Luckmann (1966). Although some members are uncomfortable vocalizing their left identity, it is apparent that their involvement in Left Alternative is related to an affinity for the alternative ideas associated with the club, as well as an implicit desire to affirm their sense of self. However, the latter theory is not conclusive, as this research is limited in analyzing how one's stated identity changes with prolonged interaction in relations which may affirm this identity. Extensive longitudinal research on the members of Left Alternative may be able to yield conclusive data regarding Berger and Luckmann's (1966) notion of identity affirmation.

This research finds conflicting evidence for Olsen's (2009) notion of selective incentives and the rational actor model it assumes. While Left Alternative offers the opportunity for members to become educated regarding socialist and other alternative ideas, and therefore provides a selective incentive, the rational actor model is challenged by the desire of members to help educate others, as well as by their activist intent. If one is to surmise, however, that the education of others is in their own immediate interest (perhaps they will learn by teaching), then the rational actor model might be upheld. Nevertheless, this does not appear to be the case, as the education of others appears to be interrelated with activist motives oriented towards the resolution of larger social problems, an objective which is inherently altruistic.

Additionally, this research does not support the conclusions of Arboleda et al. (2003) and Case (2006), which suggests that satisfaction with residence life, and on-campus residency itself, prompt further involvement in club activity. Penelope was the only member of Left Alternative who lived in residence housing. As indicated in our interview, however, neither phenomenon had any impact on her decision to participate in Left Alternative. Proximity of residency to campus was also found to be unrelated to participation in regards to those members who live off campus. 


\section{CONCLUSION}

If SFU is to regain its former prominence as a radical campus, school clubs and leftist sympathizers might benefit to acknowledge the many causes of involvement in left initiatives. Though my inquiry was limited to a single type of association, it is clear that member's involvement in Left Alternative speaks largely to the content of this club. As a club that upholds socialist and otherwise alternative perspectives, the appeal of Left Alternative is, in many ways, coterminous with the appeal of these perspectives. The prevalence of educational motives, at least concerning those members wanting to learn, and the implicit need to affirm struggling notions of self most clearly attests to this. In fact, my own involvement was prompted by the club's emphasis on socialism. For this reason, the findings of this research might plausibly extend to all left initiatives where gaining participants is a concern.

Currently, however, Left Alternative remains one of a minority of left associations at SFU. Still, this does not undermine its importance to the student body. As demonstrated, Left Alternative provides an outlet for certain marginalized sentiments. It is here that students are able to entertain notions of the self that are mostly removed from mainstream society; are able to learn about and, as the club mandate states, "discuss various social, political, economic, and cultural issues of significance to our members"; and to realize activist desires, participating in potentially meaningful change, both within SFU

and beyond. Besides the venerable Simon Fraser Public Interest Research Group, and the handful of 'action groups' beneath it, no other space is available for these purposes. Left Alternative is a last vestige of SFU's radical past and, as many members hope, a potential base for its return. 


\section{BIBLIOGRAPHY}

Arboleda, A. Wang, Y. Shelley, Mack C., and Donald F. Whalen. 2003. “Predictors of Residence Hall Involvement." Journal of College Student Development 44(4): 517-531.

Berger, Peter L. and Thomas Luckmann. 1966. The Social Construction of Reality. New York: Anchor Books.

Brym, Robert J. 2008. New Society. Toronto: Thomson.

Burns, David J., Reid, Jane S., Toncar, M., Fawcett, J., and Cynthia Anderson. 2006. "Motivationsto Volunteer: The Role of Altruism." International Review on Public and NonProfit Marketing 3(2): 79-91.

Case, Kimberly F. 2011. “A Gendered Perspective on Student Involvement in Collegiate Clubs and Organizations in Christian Higher Education." Christian Higher Education 10(3-4): 166-195.

Gilbreath, B., Jackson, Jay W., Miller, Daniel A., Frew, Erin J., and Christa Dillman. 2011.“Group Identification and University Involvement." Journal of Applied Social Psychology 41(4): 798822.

Johnston, Hugh. 2005. Radical Campus: Making Simon Fraser University. Vancouver: Douglas and McIntyre.

Knowles, Megan L., and Wendi L. Gardner. 2008. “Benefits of Membership: The Activation and Amplification of Group Identities in Response to Social Rejection." Personality \& Social Psychology Bulletin 34(9): 1200-1213.

Olsen, Mancur. 2009. "The Free-Rider Problem." In The Social Movements Reader: Cases and Concepts, edited by Goodwin, Jeff and James M. Jasper , 60-65. West Sussex: Blackwell Publishing.

Planalp, Sally, and Melanie Trost. 2009. "Motivations of Hospice Volunteers." American Journal of Hospice and Palliative Medicine 26(3): 188-192.

Stevenson, Michael. 2005. "Radical by Design." Retrieved from the SFU Website. http://www.sfu.ca/aq/issues/november2005/features/radical-by-design.html.

This work is licensed under a Creative Commons AttributionNonCommercialNoDerivs 3.0 Unported License. 